Review

\title{
Novel Findings regarding the Bioactivity of the Natural Blue Pigment Genipin in Human Diseases
}

\author{
Magdalena Bryś ${ }^{1}$, Karina Urbańska ${ }^{2}$ iD and Beata Olas $^{3, *(D)}$ \\ 1 Department of Cytobiochemistry, Faculty of Biology and Environmental Protection, University of Lodz, \\ Pomorska 141/3, 90-236 Lodz, Poland; magdalena.brys@biol.uni.lodz.pl \\ 2 Faculty of Medicine, Medical University of Lodz, 90-419 Lodz, Poland; karina.urbanska@stud.umed.lodz.pl \\ 3 Department of General Biochemistry, Faculty of Biology and Environmental Protection, University of Lodz, \\ Pomorska 141/3, 90-236 Lodz, Poland \\ * Correspondence: beata.olas@biol.uni.lodz.pl; Tel./Fax: +48-42-6354485
}

check for updates

Citation: Bryś, M.; Urbańska, K.; Olas, B. Novel Findings regarding the Bioactivity of the Natural Blue Pigment Genipin in Human Diseases. Int. J. Mol. Sci. 2022, 23, 902. https:// doi.org/10.3390/ijms29020902

Academic Editor:

Antonio González-Sarrías

Received: 27 December 2021

Accepted: 12 January 2022

Published: 14 January 2022

Publisher's Note: MDPI stays neutral with regard to jurisdictional claims in published maps and institutional affiliations.

Copyright: (C) 2022 by the authors. Licensee MDPI, Basel, Switzerland. This article is an open access article distributed under the terms and conditions of the Creative Commons Attribution (CC BY) license (https:// creativecommons.org/licenses/by/ $4.0 /)$.

\begin{abstract}
Genipin is an important monoterpene iridoid compound isolated from Gardenia jasminoides J.Ellis fruits and from Genipa americana fruits, or genipap. It is a precursor of a blue pigment which may be attractive alternative to existing food dyes and it possesses various potential therapeutic properties such as anti-cancer, anti-diabetic and hepatoprotective activity. Biomedical studies also show that genipin may act as a neuroprotective drug. This review describes new aspects of the bioactivity of genipin against various diseases, as well as its toxicity and industrial applications, and presents its potential mechanism of action.
\end{abstract}

Keywords: genipin; blue colorant; biological activity; safety

\section{Introduction}

Gardenia jasminoides J.Ellis is a popular shrub in the Rubiaceae family, which naturally grows in the laurel forests of China, Japan, Taiwan or Vietnam. Its fruits are well known, being called Zhizi in China and Sanshishi in Japan, where they are used as a natural colorant and play an important role in traditional medicine [1]. G. jasminoides fruit extract has been used as an effective oral treatment for hepatic disorders and inflammation in traditional Chinese medicine [1,2]. Furthermore, preparations containing G. jasminoides fruit extract have also been found to have good therapeutic effects on diseases of the central nervous system, such as cerebral stroke, dementia, and depression [2]. Phytochemicals from medicinal plants often offer a better and safer substitute to synthetic medication [3]. G. jasminoides fruits are also used as functional food supplements in China and East Asia, and the flowers as a food ingredient and dietary supplement, for example, in tea.

About 160 chemical compounds have been described from this plant. Of these, the primary bioactive compounds are its iridoid glycosides and yellow pigment, which demonstrate various biological activities. The most widely used iridoids isolated from the $G$. jasminoides fruit are genipin and geniposide [4,5]; however, the iridoid glycoside content can vary by $5-6 \%$ between different regions [6].

The hydrolysis of geniposide and gardenoside by the $\beta$-glucosidase results in the production of genipin, a water-soluble iridoid monoterpenoid whose maximum absorbance $(496 \mathrm{~nm})$ does not change with the $\mathrm{pH}$ of the environment. Genipin can be reacted with amino acids such as glycine, lysine or phenylalanine to obtain the blue dye gardenia blue (Figure 1) [4-7]. Studies indicate that genipin is absorbed via the intestine and transported to the liver through the portal bloodstream [8]. Although various methods exist for isolating genipin from G. jasminoides fruits, large-scale isolation is usually performed microbiologically with Penicillum nigrans; the fungus hydrolyzes the geniposide into aglycone genipin by $\beta$-glucosidase [9,10]. More details are described in review paper of Ramos-de-la-Pena [10]. 


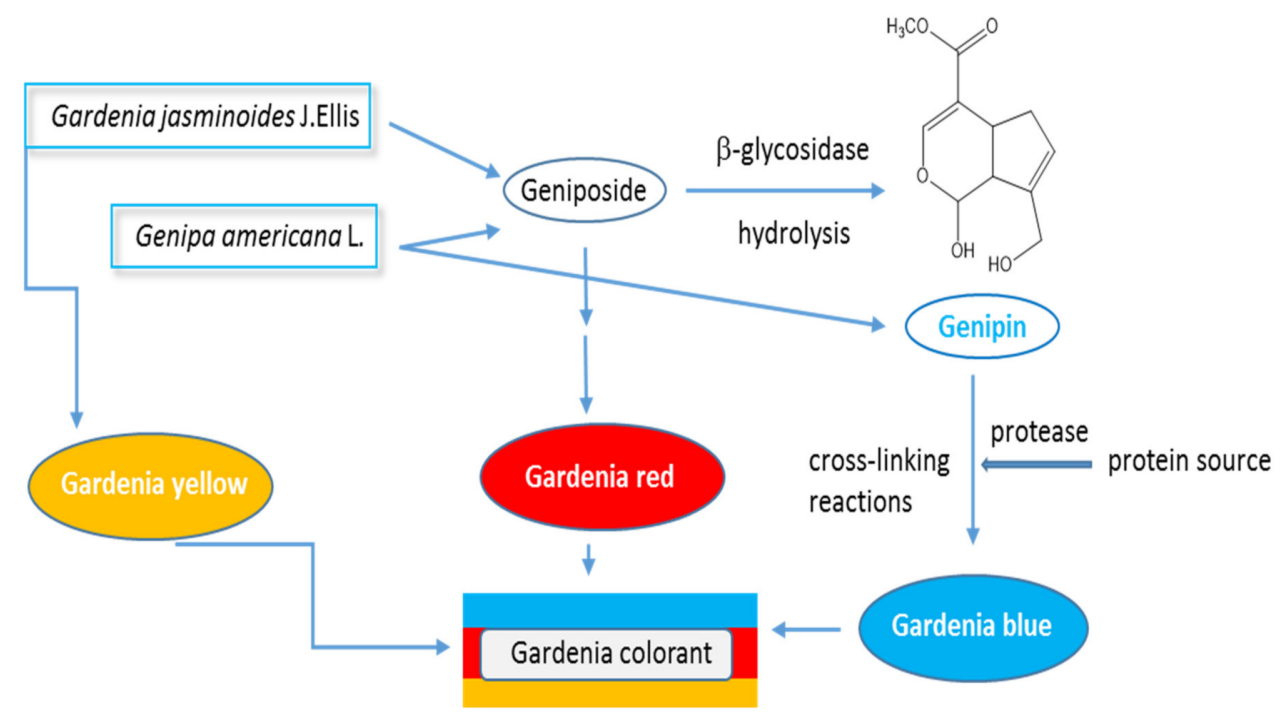

Figure 1. Sources of genipin and the conversion process of gardenia colorants (gardenia yellow and gardenia blue) [1].

Gardenia blue is not resistant to temperatures greater than $80^{\circ} \mathrm{C}$; however, it does resist changes in environmental $\mathrm{pH}$. It can thus be used for coloring both liquid products and solid products, including jellies and candies; however, dyeing jellies or candies brings with it a change of color to blue-green [4]. A similar colorant, gardenia yellow, including carotenoids obtained from the G. jasminoides fruits also has a long history of use in Asian countries. It has low allergenicity and stable chemical properties, it has antioxidant properties and is non-toxic; however, it is not yet permitted as a food colorant in the European Union and the USA [1].

Recently, two new iridoid glycosides (genipin 1,10-di-O- $\alpha$-L-rhamnoide, and genipin 1,10-di-O- $\beta$-D-xylopyranoside) were isolated from gardenia fructus, the dried fruits of $G$. jasminoides [11]. The authors note that these compounds may act as tyrosinase inhibitors and antioxidants.

Genipin may be also obtained from Genipa americana L, a plant growing in Central South America, southern Mexico, and the Caribbean. The fruit, known as genipap, chipara, maluco, jaguar, huito, and caruto, is $8-10 \mathrm{~cm}$ long, with an elliptical shape. The sources of genipin and the conversion process of gardenia colorants (gardenia yellow and gardenia blue) are presented in Figure 1.

As well as being a blue food colorant, in vitro and in vivo studies have found gardenia to have various biological properties, including antioxidant, anti-inflammatory and anticancer activity. These play important roles in its mechanisms of action and its beneficial effects on the cardiovascular, nervous and digestive systems, among others (Table 1) [1,2,8,12-15]. This review reviews the current state of knowledge regarding the bioactivity of genipin, i.e., the aglycone of geniposide, in various diseases. This review is based on studies identified in electronic databases, including PubMed, Web of Knowledge, Scopus and ScienceDirect. The last search was run on December 15, 2021. The following terms were used: "genipin" and "blue colorant". 
Table 1. Patent overview of genipin for food products [16].

\begin{tabular}{|c|c|c|}
\hline Title & Publication Number and Date & Claim \\
\hline $\begin{array}{l}\text { Stable natural color process, products and } \\
\text { use thereof. }\end{array}$ & USRE46695E (28 March 2008) & $\begin{array}{l}\text { A method of preparing colored products } \\
\text { from edible materials comprises } \\
\text { processing Genipa americana fruit juice. }\end{array}$ \\
\hline Stable natural color process and products. & WO2009120579 (6 March 2009) & $\begin{array}{l}\text { Colorant for beverages, and dietary } \\
\text { supplements. }\end{array}$ \\
\hline $\begin{array}{l}\text { Stable natural color comprising genipin } \\
\text { and derivatives. }\end{array}$ & CA2718604C (15 September 2010) & $\begin{array}{l}\text { A method of preparing colored products } \\
\text { from edible materials comprises } \\
\text { processing Genipa americana fruit juice. }\end{array}$ \\
\hline Genipin-rich substances and uses thereof. & JP2017105851A (7 November 2011) & $\begin{array}{l}\text { A method of producing a genipin rich } \\
\text { colorant from Genipa americana. }\end{array}$ \\
\hline $\begin{array}{l}\text { A process for obtaining insoluble } \\
\text { substances from genipap-extract } \\
\text { precipitates, substances from } \\
\text { genipap-extract precipitates and their } \\
\text { uses. }\end{array}$ & EP2408319A1 (25 January 2012) & $\begin{array}{l}\text { The precipitation of genipap extract } \\
\text { (Genipa americana) for obtaining a } \\
\text { substance insoluble in polar and/or } \\
\text { non-polar media for applications in an } \\
\text { food compositions. }\end{array}$ \\
\hline Genipin-rich material and its use. & $\begin{array}{l}\text { EP3238550A1 (7 November 2012) } \\
\text { US8945640B2 (3 November 2015) } \\
\text { USRE46314E (21 February 2017) }\end{array}$ & $\begin{array}{l}\text { A method of preparing genipin-rich } \\
\text { materials from the fruit of Genipa } \\
\text { americana for their use as a cross-linking } \\
\text { agent and as a raw material to produce } \\
\text { colors is disclosed. }\end{array}$ \\
\hline $\begin{array}{l}\text { Colorant compounds derived from } \\
\text { genipin or genipin containing materials. }\end{array}$ & $\begin{array}{c}\text { US9376569 (28 June 2016) } \\
\text { US10266698B2 (23 April 2019) }\end{array}$ & $\begin{array}{l}\text { Colorant compounds and methods of its } \\
\text { isolation from a reaction of genipin and } \\
\text { an amine. }\end{array}$ \\
\hline
\end{tabular}

\section{Genipin in Food Products}

Genipin from G. jasminoides is available for use in food products in East Asia, including Korea and Japan. This compound, as a blue colorant, obtained from G. americana or in combination with other fruits, is commercially exploited in European Union and the USA as concentrated fruit juices; as a colorant, it is exempt from certification [6,14]. More details about factors affecting the formation and stability of genipin are described by Neri-Numa et al. [14] The use of genipin in food products is summarized in Table 1.

\section{Hepatoprotective Properties}

The hepatoprotective effect of genipin was first noted by Jing-hua Peng [17]. Since then, genipin was found to enhance the distribution of multidrug resistance-associated protein 2 (Mrp2) to the bile canaliculi and promote mRNA and protein synthesis in hepatocytes, potentiating bilirubin disposal in vivo [18]. Elsewhere, genipin $(25-200 \mathrm{mg} / \mathrm{kg}$ ) was found to significantly decrease mortality and serum aminotransferase activity and attenuate the apoptosis of hepatocytes induced by D-galactosamine/lipopolysaccharide (LPS) [19]; it was also observed to reduce lipid peroxidation in a mouse model.

Genipin $(50 \mathrm{mg} / \mathrm{kg}$ ) has also been found to decrease oxidative stress, including lipid peroxidation, and apoptosis in mice [20]. Similarly, based on a study of C57BL/6 mice, Wang et al. [21] found that an intravenous injection of genipin $(2.5 \mathrm{mg} / \mathrm{kg})$ may protect against hepatotoxicity induced by carbon tetrachloride $\left(\mathrm{CCl}_{4}\right)$; this protection may be facilitated by attenuating the inflammatory response and inducing autophagy, which may be mediated by the mTOR (mechanistic target of rapamycin) and p38 MAPK (mitogenactivated protein kinase) signaling pathways. Seo et al. [22] also note that 25, 50, and $100 \mathrm{mg} / \mathrm{kg}$ genipin seems to prevent D-galactosamine and LPS-induced hepatic injury in mice through suppression of necroptosis-mediated inflammasome signaling.

In a mouse model, genipin effectively antagonized high-fat diet-induced hyperlipidemia and hepatic lipid accumulation by regulating the miR-142a-5p/SREBP-1c axis (sterol 
regulatory element-binding protein 1c) [23]. The authors observe that obese mice treated with genipin ( 5 and $20 \mathrm{mg} / \mathrm{kg}$ per day) demonstrated a decrease in body weight, serum lipid levels and hepatic lipid accumulation.

The hepatoprotective properties of genipin may also be based on the action of uncoupling protein 2 (UCP2), mitochondria quality regulation, anti-fibrinogenic activity, and amelioration of hepatic steatosis. However, (I) most studies on this area were conducted in vitro and on animal models, (II) the optimum effective dose of genipin in clinical application remains unknown, and (III) its selectivity and specificity for specific targets are relatively low. The therapeutic potential of genipin in various liver diseases is given in more detail by Jing-hua Peng [17] and Fan et al. [8]

Sohn et al. [24] report that genipin has protective effects on gastrointestinal disorders such as gastritis and gastric ulcers in male rats: when administered at 50 and $100 \mathrm{mg} / \mathrm{kg}$, genipin demonstrated an inhibitory effect against indomethacin-induced gastric ulcers and $\mathrm{HCl} /$ ethnol-induced acute gastritis.

\section{Neuroprotective Properties}

A key element of progression in neurodegenerative diseases, such as Alzheimer's disease and Parkinson's disease, is the development of an inflammatory response in the brain [25]. For example, higher levels of proinflammatory cytokines, such as interleukin (IL)-1 $\beta$ and IL-6, and tumor necrosis factor- $\alpha$ (TNF- $\alpha$ ), have been observed in the blood, brain, and cerebral spinal fluid in patients with Alzheimer's disease and Parkinson's. Such chronic inflammation may induce the production of free radicals, synapse dysfunction, and promote the formation of amyloid plaque and Lewy bodies. Therefore, anti-inflammatory factors, including chemical compounds, may play an important role in the prevention and treatment of neurodegenerative diseases [2]. Recent studies based on animal models and cell lines have found genipin to display anti-inflammatory potential, potentially by inhibiting nitric oxide synthase, nitric oxide production and NF-KB (nuclear factor kappa B) expression; however, it may act through other mechanisms. For example, genipin was found to inhibit the LPS-induced inflammatory response in BV2 microglial cells by activating the Nrf2 (nuclear factor erythroid 2-related factor 2) signaling pathway, in vitro and in vivo. Moreover, genipin $(\leq 20 \mu \mathrm{M})$ did not demonstrate any cytotoxicity; it also inhibited certain inflammatory mediators, such as $\mathrm{NO}$ (nitric oxide), prostaglandin $\mathrm{E}_{2}$ $\left(\mathrm{PGE}_{2}\right), \mathrm{TNF}-\alpha$ and Il-1 $\beta$, in a concentration-dependent manner, i.e., at 5, 10, and $20 \mu \mathrm{M}$ [26].

Recently, in an in vitro model based on human neuroblastoma SH-SY5Y cells, Lin et al. [27] found that the conjugation of tacrine with genipin induces autophagy against Alzheimer's disease, and that it enhances effects on acetylcholinesterase in vitro. The conjugate also appears to be a good modulator of the expression of p53 and Bcl-2 (B-cell lymphoma 2). However, the authors do not report the concentration of the conjugate used in the study.

The incidence of neurodegenerative diseases is higher in people with insulin dysregulation or insulin resistance. For example, Zhang et al. [28] note that genipin inhibits UCP2-mediated proton leak and acutely reverses beta-cell dysfunction caused by obesity and high glucose levels in isolated pancreatic islets. This is a significant finding because UCP2 negatively regulates glucose-stimulated insulin secretion.

In addition, an important component of neurological illness is chronic cerebral ischemia. Zhao et al. [29] note that genipin ( $50 \mathrm{mg} / \mathrm{kg}$ daily for 3 days) was also found to protect against cerebral ischemia-reperfusion injury in adult male C57BL/ 6 mice in vivo. In this case, genipin was believed to act by regulating the UCP2-SIRT3 (sirtuin 3) signaling pathway.

Various papers indicate that genipin may have anti-depressive properties, but the possible mechanisms are not fully understood. It has been proposed that genipin can increase the concentration of a brain-derived neutrotropic factor in the hippocampus, exerting its effect through the monoaminergic neurotransmitter system [30,31]. 
More information on the pharmacological actions of genipin for the treatment of neurodegenerative diseases of the central nervous system, including Alzheimer's disease and Parkinson's disease, and its anti-depressive activity is given in a review by Li et al. [2].

\section{The Molecular Basis of the Antitumor Activity of Genipin-An Update}

The molecular basis of the anti-tumor activity of genipin has been extensively characterized in two review articles by Habtemariam and Lentini [32] and Shanmugam et al. [33]. The papers provide a detailed description of the role of genipin in the inhibition of various stages of the neoplastic process and discuss its potential use in the treatment of various cancers. The reviews summarize the processes as diagrams. However, research has moved on since the publication of these articles and brought with it significant new findings; the evidence base now encompasses a growing number of cells from various cancers [32].

Genipin was found to demonstrate antitumor activity at all stages of the carcinogenesis process. It appears to limit cell growth and cell-cycle progression in bladder and colon cancer cells. For example, genipin was found to cause cell-cycle arrest at the G0/G1-phase and deregulation of cell cycle regulators in bladder cancer T24 and 5637 cells, to inhibit the viability and growth of bladder cancer cells and to inhibit the growth of T24 xenograft tumors [34,35].

Under the influence of genipin, bladder cancer cell cultures demonstrated an increase in the number of apoptotic cells, loss of mitochondrial membrane potential, translocation of Bax (Bcl-2 associated X) protein into mitochondria, and release of cytochrome c. Moreover, the levels of PI3K (phosphoinositide-3 kinase) and Akt phosphorylation were significantly decreased. The anti-tumor effects were reversed by overexpression of a constitutively active form of Akt [12,34].

Genipin has also shown promise in oral squamous cell carcinoma (OSCC) research. It suppressed the growth of SCC-25 and SCC-9 cells and induced apoptosis and autophagy in vitro. The studies showed a decrease in p62 expression and an increase in Beclin 1 and LC3II (light chain 3) expression. Genipin has also been shown to induce autophagy in OSCC cells by inhibiting the PI3K/Akt/mTOR pathway, a signaling pathway involved in cell proliferation, angiogenesis, transcription and translation [36].

Genipin also induces apoptosis in AGS and MKN45 gastric cells by suppressing the Stat3/Jak2/Mcl-1 pathway (signal transducer and activator of transcription 3/Janus kinase2/myeloid cell leukemia-1). In this case, genipin appears to contribute to the collapse of mitochondrial functions such as MMP (mitochondrial membrane potential) [37].

Genipin treatment of HCT116 colon cancer cells resulted in elevated expression of p53 and Bax, and caspase-3 cleavage, and decreased expression of Bcl-2. Genipin was able to reduce proliferation and promote apoptosis in colon cancer cells by inducing a signaling pathway mediated by p53/Bax [37].

Genipin has also been shown to reduce the metastasis and migration of hepatocellular carcinoma cells. Hong [38] report that it appears to suppress STAT-3 phosphorylation and nuclear translocation; the authors attribute this to the ability of genipin to bind to the Src homology-2 (SH2) domain of STAT-3. The STAT-3 (signal transducer and activator of transcription-3) can facilitate cancer progression and metastasis via various signaling pathways.

Tian et al. [39] reports that genipin appears to counteract the action of Fluoxetine (FXT). FXT was found to increase matrix metalloproteinase (MMPs) expression at the genetic and protein level, and to elevate urokinase-type plasminogen activator (uPA), NF- $\kappa \mathrm{B}$, activator protein 1 (AP-1), phosphorylated mitogen-activated protein kinase (P-p38) and phosphorylated protein kinase B (P-Akt) expression. It also downregulated the expression of tissue inhibitor metalloproteinase (TIMPs) at the gene and protein levels [37]. FXT is one of the top five psychiatric prescriptions in the United States and known to promote fat accumulation in primary mouse hepatocytes, suggesting it can promote the development of fatty liver, one of the causative factors of liver cancer [40].

Genipin is also thought to exert other potential anti-tumor mechanisms related to hypoxia and the expression of HIF-1 (hypoxia inducible factor 1) and VEGFR (vascular endothelial growth factor receptor), which have been found to play important roles in cancer 
angiogenesis progression in various cell lines. Genipin suppressed HIF-1 $\alpha$ accumulation under hypoxia, associated with the PI3K and MAPK pathways, in human liver cancer cell line (HepG2), human prostate cancer cell line (LNCaP), colon cancer cell line (HCT116), cervical carcinoma cells, and breast cancer cell line (MDA231). Genipin also suppressed the expression of VEGF and the invasion of colon cancer cells by blocking the extracellular signal-regulated kinase signaling pathway [41,42].

Genipin may also modulate the activity of drugs used in cancer therapy. Genipin enhances the antitumor effect of elesclomol in A549 lung cancer cells by blocking uncoupling protein-2 and stimulating reactive oxygen species production $[43,44]$. It also has been found to inhibit the activity of mitochondrial protein UCP2. UCP2 acts as a promoter in various cancers by creating proton leaks across the inner mitochondrial membrane; by doing so, it uncouples oxidative phosphorylation from ATP synthesis, reduces the production of reactive oxygen species and the expression of matrix metalloproteinase 2 , and induces caspase-dependent apoptosis in vitro and in vitro [45].

The combination of genipin and oxaliplatin has been found to exert synergistic antitumor effects in vitro and in vivo in colorectal cancer cell lines through the reactive oxygen species (ROS)/endoplasmic reticulum (ER) stress/BIM (Bcl-2-interacting mediator of cell death) pathway. The combination may offer significant therapeutic potential with minimal adverse effects [46]. Furthermore, genipin potentiates the cytotoxicity of cisplatin while simultaneously reducing markers of cisplatin-induced nephrotoxicity in a mouse- model study [12].

\section{Other Biological Properties of Genipin}

Genipin has also been found to possesses a range of other biological properties. Gupta et al. [47] report that genipin $(100 \mu \mathrm{M})$ reduced elevated UCP2 levels in macrophages induced by infection and that it appears to possess antileishmanial potential by suppressing of UCP2 by the host. Nguyen et al. [48] suggest that a mixture of herbal preparations consisting of ginseng radix, rhei radix et rhizoma, cimicifugae rhizoma, and gareniae fructus may have therapeutic potential in the treatment of psoriasis lesions; the mixture is known to contain, among others, chlorogenic acid, emodin, genipin, cimigenoside and ginsenoside RB1. For example, at a concentration of 1\%, application reduced psoriasislike symptoms in C57BL/6 mice previously treated with imiquimod and attenuated the production of various cytokines in skin lesions. The mixture also demonstrated synergistic properties compared to its components. Moreover, genipin administration $(30 \mathrm{mg} / \mathrm{kg} /$ day $)$ also demonstrated significant suppression of liver and spleen parasite burdens in infected mice, resulting in an elevated level of p38 mitogen-activated protein kinase, a host-favorable cytokine, in a ROS-dependent manner.

Of all the active components of the G. jasminoides fruit extract, it has been proposed that genipin has the greatest influence on T-cell suppression, which is partially mediated by activation of the ORAI1 (ORAI calcium release-activated calcium modulator 1) channel [49]. The authors suggest that this may be the mechanism by which genipin exerts its antiinflammatory effects. The studies were based on human primary $\mathrm{CD} 4^{+} \mathrm{T}$ lymphocytes, with genipin concentrations ranging from 10 to $100 \mu \mathrm{M}$.

Genipin also demonstrated antiviral activity against human (Wa) and simian (SA-11) rotavirus strains in vitro and in vivo. The authors suggest that genipin may suppress viral replication and regulate inflammatory responses. Genipin has also shown therapeutic and preventive potential in blocking white spot syndrome virus (WSSV) by inhibiting Bax inhibitor-1 gene expression; it also inhibited WSSV replication when applied at concentrations of 6.25 to $50 \mathrm{mg} / \mathrm{kg}$ by decreasing the expression of STAT (signal transducer and activator of transcription) in crayfish and shrimp [50]. In addition, genipin glycoside derivatives have also been found to have antiviral and antifungal activities [51].

Ko et al. [52] found that genipin inhibits allergic responses in ovalbumin-induced asthmatic mice. Briefly, the mice were administrated an intraperitoneal injection of ovalbumin on days 0 and 14 to boost the immune responses, following which, genipin (10 and $20 \mathrm{mg} / \mathrm{kg}$ ) was administered from day 18 to 23 by oral gavage. The authors observed that 
genipin significantly reduced the inflammatory cell count, the expression of inducible nitric oxide synthase and cyclooxygenase, as well as the activity and protein levels of matrix metalloproteinase-9 in the lung.

Li et al. [34] report that the PI3k/Akt pathway is involved in the mechanism of action of genipin in acute lung injury. Seo et al. [21] indicate that 25,50 , and $100 \mathrm{mg} / \mathrm{kg}$ genipin seems to prevent D-galactosamine and lipopolysaccharide-induced hepatic injury in mice through suppression of necroptosis-mediated inflammasome signaling. Elsewhere, genipin was found to also have an anti-aging effect on chondrocytes, and to demonstrate antioxidative properties in old rat hearts when administered at 5 to $10 \mathrm{M}$ for 15 min before prolonged ischemia [33].

A study of spontaneously hypertensive rats found that genipin decreases blood pressure and that genipin appears to improve renal function by decreasing serum creatinine, urinary microalbumin, $N$-acetyl- $\beta$-D-glucosaminidase, and blood urea nitrogen [53]. Zhang et al. [54] suggest that genipin $(1,1.25$, and $5 \mathrm{mg} / \mathrm{kg})$ protects against LPS-induced acute lung injury by inhibiting the NFKB and NLR family pyrin domain containing 3 (NLRP3) signaling pathways in mice. In addition, 2 and $5 \mathrm{mg} / \mathrm{kg}$ genipin appears to protect against apoptosis and inflammation in LPS-induced acute lung injury by promoting autophagy [55].

Wang et al. [56] observed that genipin reduces the expression of miR-29a, miR-29b and miR-29c in the sclera of myopic eyes. The expression was determined using PCR. In addition, this compound inhibited the protein expression of matrix metalloproteinase 2 (MMP2) and increased the expression of the collagen alpha1 chain of type 1 (COL1A1); the authors suggest that genipin may be a promising agent for treating high myopia. This study was based on a model of myopia where guinea pigs were treated with a $-8 \mathrm{D}$ lens on both eyes for 21 days. Eyes with a refractive error of $-6 \mathrm{D}$ or greater were selected for the experiments. The scleral samples in the control group and myopia group were incubated in normal saline or in $1 \%$ genipin at $24^{\circ} \mathrm{C}$. Other experiments suggest that genipin (5-100 $\mu \mathrm{M}$ ) may protect against injury induced by $100 \mu \mathrm{M}$ or $200 \mu \mathrm{M} \mathrm{H}_{2} \mathrm{O}_{2}$ in retinal pigment epithelial cells via the Nrf2 signaling pathway.

Genipin ( $25 \mathrm{mg} / \mathrm{kg}$ ) improves reproductive health problems caused by a circadian disruption in male mice. The authors observed that exogenous genipin alleviated damage to fertility and spermatogenesis induced by circadian disruption. It also normalized the levels of various hormones, including androstenedione, testosterone and dihydrotestosterone in male mice. Genipin also restored the reduction of key proteins involved in steroidogenesis.

Recently, Zhang et al. [28] report that combined genipin (50 mg/kg) and insulin $(10 \mathrm{IU} / \mathrm{kg}$ ) treatment improves implant osseointegration in type 2 diabetic rats, and that this may be related to the AMPK (adenosine monophosphate-activated protein kinase) signaling pathway.

The biological properties of genipin in vitro and in vivo are summarized in Table 2, and the therapeutic potential of genipin for different diseases and the main signaling molecular pathways of genipin are given in Figures 2 and 3. More details about signaling pathways for genipin are described in other review papers [2,8]. However, in the absence of the identification of at least one direct cellular target of genipin (or its metabolites), its specificity of action remains vague. For example, recently, Li et al. [2] have also described that more work is required on identifying target molecules of genipin that are involved in signaling pathways that modulate neutrophic properties. Molecular targets for hepatoprotective properties of genipin are also different. 
Table 2. Biological properties of genipin in various experimental models.

\begin{tabular}{|c|c|c|c|c|}
\hline $\begin{array}{l}\text { Compound and Its } \\
\text { Concentration }\end{array}$ & Length of Study & Experimental Model & Biological Properties & References \\
\hline Genipin $(2.5-1000 \mu \mathrm{M})$ & - & $\begin{array}{l}\text { In vitro-U87MG and } \\
\text { A172 cell lines }\end{array}$ & Anticancer action & [57] \\
\hline $\begin{array}{c}\text { Geniposide and } \\
\text { genipin }(0.03-0.25 \mathrm{mM}) \\
\text { Total of } 31 \text { and } 62 \\
\mathrm{mg} / \mathrm{kg} / \text { day for } \\
\text { geniposide, } \\
\text { Total of } 18 \text { and } 36 \\
\mathrm{mg} / \mathrm{kg} / \text { day for } \\
\text { genipin }\end{array}$ & $\begin{array}{l}\text { In vitro- }-3,6 \text { and } 24 \mathrm{~h} \\
\text { In vivo- } 1 \text { week }\end{array}$ & $\begin{array}{l}\text { In vitro-AGS cells } \\
\text { In vivo-C57BL } / 6 \\
\text { mice }\end{array}$ & $\begin{array}{l}\text { Reducing H. pylori } \\
\text { infections }\end{array}$ & [58] \\
\hline $\begin{array}{c}\text { Genipin (500 nM-200 } \\
\mu \mathrm{M})\end{array}$ & $24 \mathrm{~h}$ & $\begin{array}{c}\text { In vitro-pancreatic } \\
\text { adenocarcinoma } \\
\text { PaCa44, PaCa3, Panc1, } \\
\text { MiaPaCa2 and T3M4 }\end{array}$ & Anticancer action & [59] \\
\hline $\begin{array}{c}\text { Genipin (10 and } 75 \\
\mu \mathrm{g} / \mathrm{mL}, 3-74 \mathrm{mg} / \mathrm{kg} \\
\text { bw/day) }\end{array}$ & $\begin{array}{l}\text { In vitro- }-4 \text { and } 24 \mathrm{~h} \\
\text { In vivo- } 24 \mathrm{~h}\end{array}$ & $\begin{array}{l}\text { In vitro-human TP53 } \\
\text { component human } \\
\text { lymphoblast TK3 cells } \\
\text { In vivo-B6C3F1 mice }\end{array}$ & Anticancer action & {$[60]$} \\
\hline Genipin (50 mg/kg) & $24 \mathrm{~h}$ & $\begin{array}{l}\text { In vivo-red swamp } \\
\text { crayfish P. clarkii }\end{array}$ & Antiviral action & [50] \\
\hline Genipin $(20-50 \mu \mathrm{M})$ & $24 \mathrm{~h}$ & $\begin{array}{c}\text { In vitro-human } \\
\text { colorectal cancer cell } \\
\text { lines-HCT16 and } \\
\text { DLD-1 }\end{array}$ & $\begin{array}{l}\text { Therapeutic potential } \\
\text { with a minimal adverse } \\
\text { effect of oxaliplatin }\end{array}$ & [46] \\
\hline Genipin $(50 \mu \mathrm{M})$ & $24 \mathrm{~h}$ & $\begin{array}{l}\text { In vitro-human colon } \\
\text { cancer lines: HCT116 } \\
\text { and HT29, human } \\
\text { breast cancer cell } \\
\text { line-SKBR-3, human } \\
\text { prostate cancer cell } \\
\text { line-DU145 }\end{array}$ & Anticancer action & [41] \\
\hline $\begin{array}{c}\text { Genipin }(10-200 \mu \mathrm{M}, 20 \\
\text { and } 50 \mathrm{mg} / \mathrm{kg} / \text { three } \\
\text { times/week })\end{array}$ & $\begin{array}{c}\text { In vitro-48 } \\
\text { hIn vivo-4 weeks }\end{array}$ & $\begin{array}{c}\text { In vitro-human } \\
\text { bladder cancer cells: } \\
\text { T24 and } 5637 \\
\text { In vivo-BALB/c } \\
\text { (nu/nu) mice }\end{array}$ & Anticancer action & [34] \\
\hline $\begin{array}{l}\text { Genipap fruit extract } \\
(60.77 \mathrm{mg} / \mathrm{g} \\
\mathrm{fdw}-\text { concentration of } \\
\text { genipini) }\end{array}$ & - & $\begin{array}{l}\text { In vitro-the tumor cell } \\
\text { lines U251 (glioma), } \\
\text { MCF-7 (breast), } \\
\text { NCI-ADR/RES (breast } \\
\text { expressing the multiple } \\
\text { drug resistance } \\
\text { phenotype), 786-0 } \\
\text { (renal), NCI-H460 } \\
\text { (lung, non-small cells), } \\
\text { PC-3 (prostate), HT-29 } \\
\text { (colon) and K562 } \\
\text { (leukaemia) }\end{array}$ & $\begin{array}{l}\text { Antioxidant and } \\
\text { antiproliferative effect }\end{array}$ & [14] \\
\hline $\begin{array}{c}\text { Genipin (25-100 } \\
\mathrm{mg} / \mathrm{kg})\end{array}$ & - & In vivo-ICR mice & $\begin{array}{c}\text { Ameliorating } \\
\text { LPS-induced } \\
\text { hepatocellular damage }\end{array}$ & [22] \\
\hline
\end{tabular}


Table 2. Cont.

\begin{tabular}{|c|c|c|c|c|}
\hline $\begin{array}{l}\text { Compound and Its } \\
\text { Concentration }\end{array}$ & Length of Study & Experimental Model & Biological Properties & References \\
\hline Genipin (100 mg/kg) & - & $\begin{array}{l}\text { In vivo }-\mathrm{C} 57 \mathrm{BL} / 6 \\
\text { mice }\end{array}$ & $\begin{array}{c}\text { Protecting the liver from } \\
\text { ischemia/reperfusion } \\
\text { injury }\end{array}$ & [61] \\
\hline $\begin{array}{l}\text { Genipin }(5-20 \mu \mathrm{M}, 1-5 \\
\mathrm{mg} / \mathrm{kg})\end{array}$ & $\begin{array}{c}\text { In vitro-24 } \\
\text { hIn vivo-3 week }\end{array}$ & $\begin{array}{c}\text { In vitro-BV2 } \\
\text { microglia cells } \\
\text { In vivo-ICR mice }\end{array}$ & $\begin{array}{l}\text { Inhibiting LPS-induced } \\
\text { inflammatory response }\end{array}$ & [6] \\
\hline $\begin{array}{c}\text { Genipin }(1-400 \mu \mathrm{M}, 30 \\
\mathrm{mg} / \mathrm{kg})\end{array}$ & $\begin{array}{c}\text { In vitro-72 } \\
\text { hIn vivo-week }\end{array}$ & $\begin{array}{c}\text { In vitro-human } \\
\text { tongue squamous } \\
\text { In vivo-BALB/c nude } \\
\text { mice }\end{array}$ & Anticancer action & [36] \\
\hline $\begin{array}{l}\text { Genipin (50 and } 100 \\
\mu \mathrm{M}, 50 \text { and } 100 \mathrm{mg} / \mathrm{kg} \text { ) }\end{array}$ & - & $\begin{array}{c}\text { In vitro-AGS gastric } \\
\text { cancer cells } \\
\text { In vivo-Sprague- } \\
\text { Dawley } \\
\text { rats }\end{array}$ & Gastroprotective effect & [24] \\
\hline Genipin (50 mg/kg) & 3 days & $\begin{array}{l}\text { In vivo }-\mathrm{C} 57 \mathrm{BL} / 6 \\
\text { mice }\end{array}$ & $\begin{array}{c}\text { Protecting against cerebral } \\
\text { ischemia-reperfusion } \\
\text { injury }\end{array}$ & {$[62]$} \\
\hline Genipin (50 mg/kg) & - & In vivo-mice & $\begin{array}{c}\text { Hepatoprotection against } \\
\text { ischemia/reperfusion } \\
\text { injury }\end{array}$ & [20] \\
\hline Genipin $(2.5 \mathrm{mg} / \mathrm{kg})$ & Genipin $2 \mathrm{~h}$ before $\mathrm{CCl}_{4}$ & In vivo-rats & $\begin{array}{l}\text { Hepatoprotective effect in } \\
\text { the presence } \mathrm{CCl}_{4}\end{array}$ & [21] \\
\hline $\begin{array}{l}\text { Genipin ( } 5 \text { and } 20 \\
\mathrm{mg} / \mathrm{kg} \text { per day) }\end{array}$ & 9 weeks & In vivo-obese mice & $\begin{array}{l}\text { Alleviating hepatic lipid } \\
\text { accumulation }\end{array}$ & [23] \\
\hline Genipin $(25$ mg/kg) & - & In vivo-male mice & $\begin{array}{l}\text { Improving reproductive } \\
\text { health problems }\end{array}$ & [63] \\
\hline Genipin $(5-100 \mu \mathrm{M})$ & - & $\begin{array}{c}\text { In vitro-retinal } \\
\text { pigment epithelial cells }\end{array}$ & Antioxidant activity & [29] \\
\hline $\begin{array}{c}\text { Genipin } \\
(100 \mu \mathrm{M}-\text { in vitro; } 30 \\
\mathrm{mg} / \mathrm{kg} / \text { day-in vivo })\end{array}$ & - & $\begin{array}{l}\text { In vitro-macrophages } \\
\text { In vivo-infected mice }\end{array}$ & Antileishmanial effect & [47] \\
\hline $\begin{array}{c}\text { Genipin } \\
(10-200 \mu \mathrm{M}-\text { in vitro; } \\
100 \\
\mathrm{mg} / \mathrm{kg} / \text { day-in vivo })\end{array}$ & - & $\begin{array}{l}\text { In vitro-murine } \\
\text { macrophages } \\
\text { RAW264.7 cells } \\
\text { In vivo-mice }\end{array}$ & Antiviral effect & {$[64]$} \\
\hline $\begin{array}{c}\text { Genipin (10 and } 20 \\
\mathrm{mg} / \mathrm{kg})\end{array}$ & - & In vivo-mice & $\begin{array}{l}\text { Inhibiting allergic } \\
\text { responses }\end{array}$ & [52] \\
\hline Genipin (1\%) & & $\begin{array}{l}\text { In vitro-myopic eyes } \\
\text { of guinea pigs }\end{array}$ & $\begin{array}{c}\text { Therapeutic potential in } \\
\text { myopia }\end{array}$ & {$[56]$} \\
\hline $\begin{array}{l}\text { Conjugate of genipin } \\
\text { and tacrine }\end{array}$ & - & $\begin{array}{l}\text { In vitro-SH-SY5Y } \\
\text { cells }\end{array}$ & $\begin{array}{c}\text { Inhibiting } \\
\text { acetylcholinesterase }\left(\mathrm{IC}_{50}\right. \\
\text { about } 5.8 \mathrm{nM})\end{array}$ & [27] \\
\hline $\begin{array}{l}\text { The mixture of herbal } \\
\text { combinations, } \\
\text { containing genipin } \\
(1 \%)\end{array}$ & - & $\begin{array}{l}\text { In vivo-C57BL } / 6 \\
\text { mice }\end{array}$ & $\begin{array}{l}\text { Therapeutic potential in } \\
\text { the treatment of psoriasis } \\
\text { lesions }\end{array}$ & [65] \\
\hline $\begin{array}{l}\text { Genipin }(50 \mathrm{mg} / \mathrm{kg}) \\
\text { and insulin }(10 \mathrm{IU} / \mathrm{kg})\end{array}$ & - & $\begin{array}{l}\text { In vivo-type } 2 \\
\text { diabetic rats }\end{array}$ & $\begin{array}{l}\text { Improving implant } \\
\text { osseointegration }\end{array}$ & [27] \\
\hline
\end{tabular}




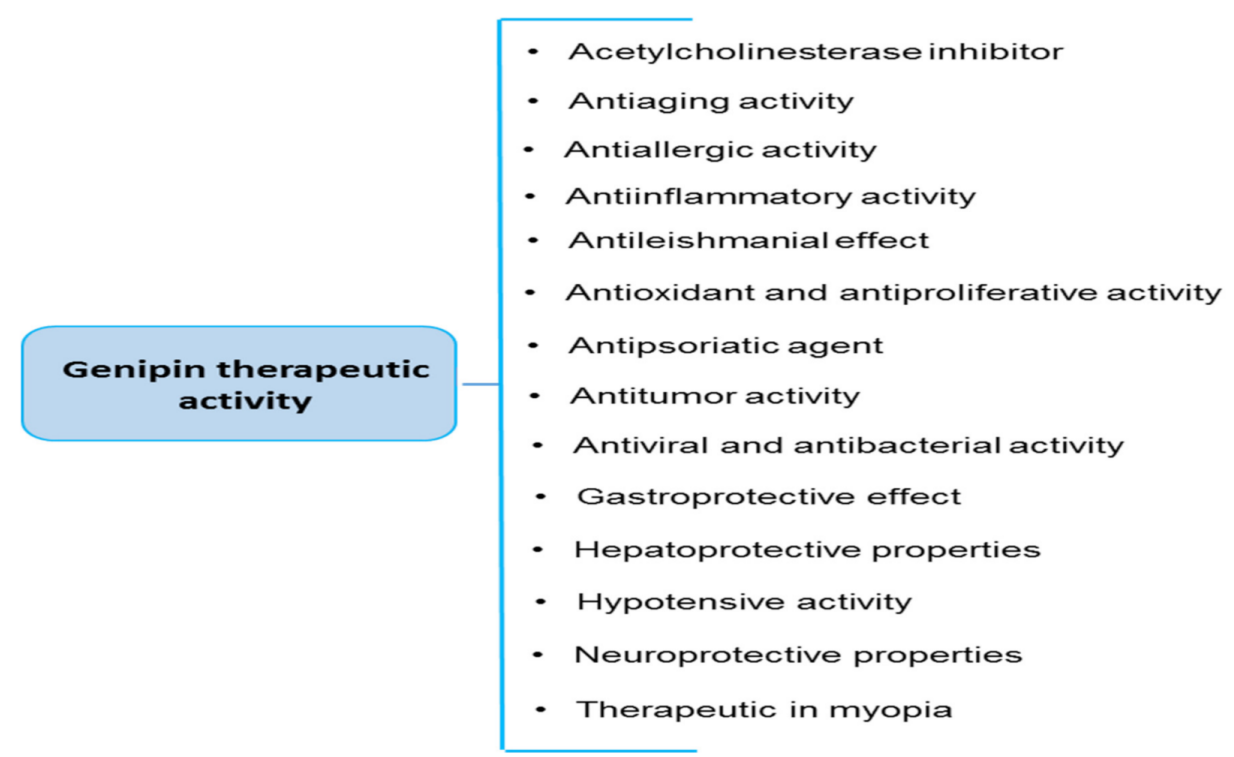

Figure 2. Therapeutic potential of genipin for different diseases (modified, [2]).

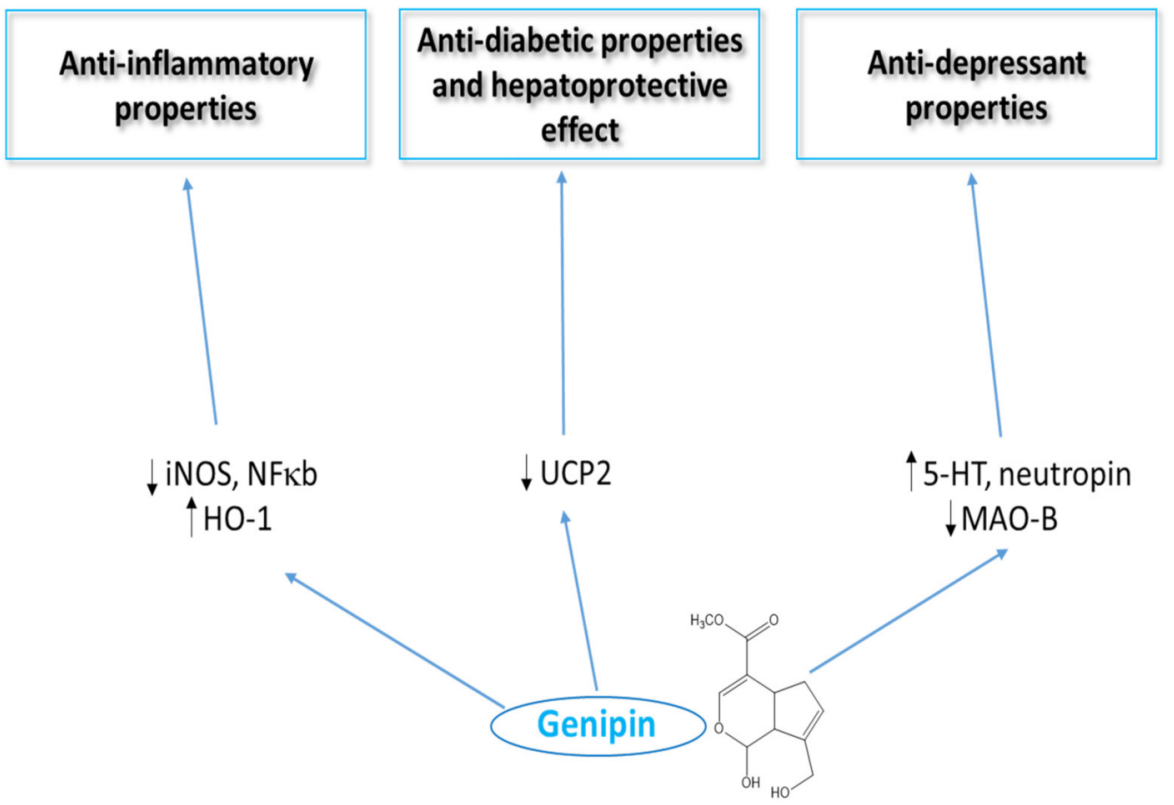

Figure 3. Selected signaling pathways for genipin (modified, $[2,8]$ ).

In addition, all the data reported in this review paper, on both cellular and animal models, are based on extremely high doses of genipin administered, which prompt for pharmacological application of the molecular excluding the use as a natural supplement. Therefore, a particularly important goal would be to determine appropriate therapeutic doses of genipin. Moreover, from a pharmacological point of view, future experiments should explain the broad spectrum of biological activity of genipin. They may also exclude genipin with the category of Pan-assay interference compounds (PAINS) that often give false positive results in high-throughput screens [66].

\section{Genipin as a Crosslinking Compound}

As a natural, water-soluble substance, genipin has been extensively studied as a non-cytotoxic crosslinking compound. Such crosslinking reactions between genipin and biopolymers are suitable for the food industry, pharmacological, and biomedical fields [9]. As genipin can crosslink proteins such as collagen and gelatin, and saccharides such as 
chitosan, it may be used for biomaterial production. Ma et al. [67] found that genipincrosslinked chitosan can serve as a matrix for the biodegeneration of synthetic dyes. In other studies, a genipin-crosslinked human albumin coating with a tannic acid layer appeared to enhance uptake of orally administered curcumin in the treatment of ulcerative colitis. This is a very interesting experiment, because curcumin is an effective treatment but is instable in the digestive tract and has a short retention time in the colon [68]. Li et al. [34] demonstrated that genipin can act as an effective hemostatic agent by crosslinking microspheres and can enhance the stability and anti-cancer properties of curcumin by stabilizing caseinate-chitosan nanoparticles.

Genipin was found to be effective in immobilizing BMP-2 (bone morphogenetic protein-2) on roughened zirconia surfaces for enhancing cell adhesion and mineralization in dental implant applications. It also offers potential in biocatalyst design, particularly in food modifications [69]. The physicochemical characteristics of genipin-cross-linked hydrogels, as well as various information on the use of biomaterials for drug delivery, including ocular drug delivery, buccal drug delivery, anti-inflammatory drug delivery, oral drug delivery, are given in a recent review by $\mathrm{Xu}$ et al. [70].

\section{Toxicity of Genipin}

According to the ChemIDplus database, the LD50 genipin is $237 \mathrm{mg} / \mathrm{kg}$ (oral route) and $153-190 \mathrm{mg} / \mathrm{kg}$ (intraperitoneal route) for mice, and $>50 \mathrm{mg} / \mathrm{kg}$ (oral route) for rats [7].

The toxicity of genipin has not been well investigated. However, Hoobs et al. [60] that genipin administered to mice, $74 \mathrm{mg} / \mathrm{kg}$ b.w. per day for males and $222 \mathrm{mg} / \mathrm{kg}$ b.w. for females, induces micronuclei in peripheral blood cells, nor did they cause DNA damage in the liver, duodenum, or stomach tissues. A recent study of zebrafish embryos by Xia et al. [71] found that treatment with $50 \mu \mathrm{g} / \mathrm{mL}$ genipin reduced hatching rates and body length, and induced nephrotoxicity, hepatotoxicity and cardiotoxicity. The authors suggest that a key role may be played by oxidative stress, particularly lipid peroxidation, measured by malondialdehyde level, and the concentration of reactive oxygen species.

However, Kim et al. [72] indicate that the blue pigment obtained from Gardenia jasminoides J.Ellis exhibits low cytotoxicity, and that it is effective in staining plaque, allowing it to be used as a natural dental plaque disclosant. Although the authors do not refer directly to genipin in the their study, it is known that it is the natural precursor of the pigment used in the study. Although genipin itself is colorless, it acquires its blue color by a reaction with primary amino acids and protein hydrolysates.

\section{Conclusions}

Genipin is a suitable natural blue colorant precursor for food products. Moreover, this review describes new data regarding its bioactivity, its antitumor, anti-diabetic and neuroprotective activities, and other clinically relevant topics. Particularly noteworthy is the fact that genipin demonstrates anti-cancer properties, which it exerts at all stages of the process, from proliferation, through apoptosis, to inhibition of migration and metastasis. Most importantly, in vitro and in vivo studies indicate that it is not toxic to normal cells. Hence, genipin offers promise as an effective anti-cancer agent and as a strong cross-linking drug that can be used in the development of new and effective drugs.

Compared with results published from in vitro models, few in vivo studies have examined the biological activity of genipin and its mechanism of action remains also poorly defined.

Author Contributions: M.B. and K.U. had responsibility for part-Conclusion and the part concerning the anticancer activity of genipin; B.O. had responsibility for part-Introduction and the other properties of genipin. All authors have read and agreed to the published version of the manuscript.

Funding: This research received no external funding.

Institutional Review Board Statement: Not applicable. 


\section{Informed Consent Statement: Not applicable.}

Data Availability Statement: Not applicable.

Conflicts of Interest: The authors declare no conflict of interest.

\section{References}

1. Chen, L.; Li, M.; Yang, Z.; Tao, W.; Wang, P.; Tian, X.; Li, X.; Wang, W. Gardenia jasminoides Ellis: Ethnopharmacology, phytochemistry, and pharmacological and industrial applications of an important traditional Chinese medicine. J. Ethnopharmacol. 2020, 257, 112829. [CrossRef]

2. Li, Y.; Li, L.; Hölscher, C. Therapeutic Potential of Genipin in Central Neurodegenerative Diseases. CNS Drugs 2016, 30, 889-970. [CrossRef]

3. Surguchov, A.; Bernal, L.; Surguchev, A.A. Phytochemicals as Regulators of Genes Involved in Synucleinopathies. Biomolecules 2021, 11, 624. [CrossRef]

4. Krępska, M.; Lasoń-Rydel, M.; Jagiełło, J. Charakterystyka, właściwości, perspektywy i trudności stosowania niebieskich barwników naturalnych do barwienia produktów spożywczych. Technol. Jakość. Wyr. 2016, 61, 63-68.

5. Li, J.; Shi, J.; Li, P.; Guo, X.; Wang, T.; Liu, A. Genipin attenuates hyperoxia-induced lung injury and pulmonary hypertension via targeting glycogen synthase kinase-3 beta in neonatal rats. Nutrition 2019, 57, 237-244.

6. Xiao, W.; Li, S.; Wang, S.; Ho, C.-T. Chemistry and bioactivity of Gardenia jasminoides. J. Food Drug Anal. 2016, 25, 43-61. [CrossRef]

7. Gardenia Blue. Available online: https://pubchem.ncbi.nlm.nih.gov/substance/48413323 (accessed on 13 December 2021).

8. Fan, X.; Lin, L.; Cui, B.; Zhao, T.; Mao, L.; Song, Y.; Wang, X.; Feng, H.; Qingxiang, Y.; Zhang, J.; et al. Therapeutic potential of genipin in various acute liver injury, fulminant hepatitis, NAFLD and other non-cancer liver diseases: More friend than foe. Pharmacol. Res. 2020, 159, 104945. [CrossRef]

9. Manickam, B.; Sreedharan, R.; Elumalai, M. “Genipin”-The natural water soluble cross-linking agent and its importance in the modified drug delivery systems: An overview. Curr. Drug Deliv. 2014, 11, 139-145.

10. Ramos-de-la-Peña, A.M.; Renard, C.M.G.C.; Montañez, J.; de la Luz Reyes-Vega, M.; Contreras-Esquivel, J.C. A review through recovery, purification and identification of genipin. Phytochem. Rev. 2014, 15, 37-49.

11. Shu, P.; Yu, M.; Zhu, H.; Luo, Y.; Li, Y.; Li, N.; Zhang, H.; Zhang, J.; Liu, G.; Wei, X.; et al. Two new iridoid glycosides from Gardeniae Fructus. Carbohydr. Res. 2021, 501, 108259.

12. Chestnut, C.; Subramaniam, D.; Dandawate, P.; Padhye, S.; Taylor, J., 3rd; Weir, S.; Anant, S. Targeting Major Signaling Pathways of Bladder Cancer with Phytochemicals: A Review. Nutr. Cancer 2020, 73, 1-23.

13. Lv, S.; Ding, Y.; Zhao, H.; Liu, S.; Zhang, J.; Wang, J. Therapeutic Potential and Effective Components of the Chinese Herb Gardeniae Fructus in the Treatment of Senile Disease. Aging Dis. 2018, 9, 1153-1164. [CrossRef]

14. Neri-Numa, I.A.; Pessoa, M.G.; Paulino, B.N.; Pastore, G.M. Genipin: A natural blue pigment for food and health purposes Trends Food Sci. Technol. 2017, 67, 271-279. [CrossRef]

15. Olas, B.; Białecki, J.; Urbańska, K.; Bryś, M. The Effects of Natural and Synthetic Blue Dyes on Human Health: A Review of Current Knowledge and Therapeutic Perspectives. Adv. Nutr. 2021, 12, 2301-2311. [CrossRef]

16. Xia, Z.-S.; Hao, E.-W.; Wei, Y.-T.; Hou, X.-T.; Chen, Z.-M.; Wei, M.; Du, Z.-C.; Deng, J.-G. Genipin induces developmental toxicity through oxidative stress and apoptosis in zebrafish. Comp. Biochem. Physiol. Part C Toxicol. Pharmacol. 2021, 241, 108951. [CrossRef]

17. Jing-hua Peng, S.M. The Role of Genipin and Geniposide in Liver Diseases: A Review. Altern. Integr. Med. 2013, 2, 1-8.

18. Okada, K.; Shoda, J.; Kano, M.; Suzuki, S.; Ohtake, N.; Yamamoto, M.; Takahashi, H.; Utsunomiya, H.; Oda, K.; Sato, K.; et al Inchinkoto, a herbal medicine, and its ingredients dually exert Mrp2/MRP2-mediated choleresis and Nrf2-mediated antioxidative action in rat livers. Am. J. Physiol. Gastrointest. Liver Physiol. 2007, 292, G1450-G1463.

19. Kim, S.-J.; Kim, J.-K.; Lee, D.-U.; Kwak, J.-H.; Lee, S.-M. Genipin protects lipopolysaccharide-induced apoptotic liver damage in d-galactosamine-sensitized mice. Eur. J. Pharmacol. 2010, 635, 188-193. [CrossRef]

20. Kim, J.; Kim, H.-Y.; Lee, S.-M. Protective Effects of Geniposide and Genipin against Hepatic Ischemia/Reperfusion Injury in Mice. Biomol. Ther. 2013, 21, 132-137. [CrossRef]

21. Wang, Y.; Zhao, T.; Deng, Y.; Hou, L.; Fan, X.; Lin, L.; Zhao, W.; Jiang, K.; Sun, C. Genipin Ameliorates Carbon TetrachlorideInduced Liver Injury in Mice via the Concomitant Inhibition of Inflammation and Induction of Autophagy. Oxidative Med. Cell. Longev. 2019, 2019, 3729051. [CrossRef]

22. Seo, M.-J.; Hong, J.-M.; Kim, S.-J.; Lee, S.-M. Genipin protects D-galactosamine and lipopolysaccharide-induced hepatic injury through suppression of the necroptosis-mediated inflammasome signaling. Eur. J. Pharmacol. 2017, 812, 128-137. [CrossRef]

23. Zhong, H.; Chen, K.; Feng, M.; Shao, W.; Wu, J.; Chen, K.; Liang, T.; Liu, C. Genipin alleviates high-fat diet-induced hyperlipidemia and hepatic lipid accumulation in mice via miR-142a-5p/SREBP-1c axis. FEBS J. 2018, 285, 501-517.

24. Sohn, Y.A.; Hwang, I.Y.; Lee, S.Y.; Cho, H.S.; Jeong, C.S. Protective Effects of Genipin on Gastrointestinal Disorders. Biol. Pharm. Bull. 2017, 40, 151-154. [CrossRef]

25. Surguchov, A. Biomarkers in Parkinson's disease. Biomarkers 2021, 63, 155-180.

26. Wang, J.; Chen, L.; Liang, Z.; Li, Y.; Yuan, F.; Liu, J.; Tian, Y.; Hao, Z.; Zhou, F.; Liu, X.; et al. Genipin Inhibits LPS-Induced Inflammatory Response in BV2 Microglial Cells. Neurochem. Res. 2017, 42, 2769-2776. [CrossRef] 
27. Lin, R.; Rao, S.; Li, Y.; Zhang, L.; Xu, L.; He, Y.; Liu, Z.; Chen, H. Conjugation of tacrine with genipin derivative not only enhances effects on AChE but also leads to autophagy against Alzheimer's disease. Eur. J. Med. Chem. 2021, 211, 113067. [CrossRef]

28. Zhang, C.Y.; Parton, L.E.; Ye, C.P.; Krauss, S.; Shen, R.; Lin, C.T.; Porco, J.A., Jr.; Lowell, B.B. Genipin inhibits UCP2-mediated proton leak and acutely reverses obesity- and high glucose-induced beta cell dysfunction in isolated pancreatic islets. Cell Metab. 2006, 3, 417-427.

29. Zhao, B. Genipin protects against $\mathrm{H}_{2} \mathrm{O}_{2}$-induced oxidative damagein retinal pigment epithelial cells by promoting Nrf2 signaling. Int. J. Mol. Med. 2019, 43, 936-944.

30. Wang, Q.-S.; Tian, J.-S.; Cui, Y.-L.; Gao, S. Genipin is active via modulating monoaminergic transmission and levels of brainderived neurotrophic factor (BDNF) in rat model of depression. Neuroscience 2014, 275, 365-373. [CrossRef]

31. Chen, J.-L.; Shi, B.-Y.; Xiang, H.; Hou, W.-J.; Qin, X.-M.; Tian, J.-S.; Du, G.-H. 1H NMR-based metabolic profiling of liver in chronic unpredictable mild stress rats with genipin treatment. J. Pharm. Biomed. Anal. 2015, 115, 150-158. [CrossRef]

32. Habtemariam, S.; Lentini, G. Plant-Derived Anticancer Agents: Lessons from the Pharmacology of Geniposide and Its Aglycone, Genipin. Biomedicines 2018, 6, 39. [CrossRef]

33. Shanmugam, M.K.; Shen, H.; Tang, F.R.; Arfuso, F.; Rajesh, M.; Wang, L.; Kumar, A.P.; Bian, J.; Goh, B.C.; Bishayee, A.; et al. Potential role of genipin in cancer therapy. Pharmacol. Res. 2018, 133, 195-200. [CrossRef]

34. Li, Z.; Zhang, T.B.; Jia, D.H.; Sun, W.Q.; Wang, C.L.; Gu, A.Z.; Yang, X.M. Genipin inhibits the growth of human bladder cancer cells via inactivation of PI3K/Akt signaling. Oncol. Lett. 2017, 15, 2619-2624. [CrossRef]

35. Ye, J.; Li, J.; Wang, X.; Li, L. Medicinal supplement genipin induces p53 and Bax-dependent apoptosis in colon cancer cells. Oncol. Lett. 2018, 16, 2957-2964. [CrossRef]

36. Wei, M.; Wu, Y.; Liu, H.; Xie, C. Genipin Induces Autophagy and Suppresses Cell Growth of Oral Squamous Cell Carcinoma via PI3K/AKT/MTOR Pathway. Drug Des. Dev. Ther. 2020, 14, 395-405. [CrossRef]

37. Jo, M.J.; Jeong, S.; Yun, H.K.; Kim, D.Y.; Kim, B.R.; Kim, J.L.; Na, Y.J.; Park, S.H.; Jeong, Y.A.; Kim, B.G.; et al. Genipin induces mitochondrial dysfunction and apoptosis via downregulation of Stat3/mcl-1 pathway in gastric cancer. BMC Cancer 2019, 19, 739.

38. Hong, M.; Lee, S.; Clayton, J.; Yake, W.; Li, J. Genipin suppression of growth and metastasis in hepatocellular carcinoma through blocking activation of STAT-3. J. Exp. Clin. Cancer Res. 2020, 39, 146. [CrossRef]

39. Tian, Y.-S.; Chen, K.-C.; Zulkefli, N.D.; Maner, R.S.; Hsieh, C.-L. Evaluation of the Inhibitory Effects of Genipin on the FluoxetineInduced Invasive and Metastatic Model in Human HepG2 Cells. Molecules 2018, 23, 3327. [CrossRef]

40. Feng, X.-M.; Xiong, J.; Qin, H.; Liu, W.; Chen, R.-N.; Shang, W.; Ning, R.; Hu, G.; Yang, J. Fluoxetine Induces Hepatic Lipid Accumulation Via Both Promotion of the SREBP1c-Related Lipogenesis and Reduction of Lipolysis in Primary Mouse Hepatocytes. CNS Neurosci. Ther. 2012, 18, 974-980. [CrossRef]

41. Lee, S.-Y.; Kim, H.J.; Oh, S.C.; Lee, D.-H. Genipin inhibits the invasion and migration of colon cancer cells by the suppression of HIF-1 $\alpha$ accumulation and VEGF expression. Food Chem. Toxicol. 2018, 116, 70-76. [CrossRef]

42. Jin, C.E.; Lee, J.H.; Kim, G.J.; Lee, T.H. Genipin Inhibits Hypoxia-Induced Accumulation of HIF-1 $\alpha$ and VEGF Expressions in Human Cervical Carcinoma Cells. Kosin Med. J. 2019, 34, 106-116. [CrossRef]

43. Lee, J.H.; Cho, Y.S.; Jung, K.-H.; Park, J.W.; Lee, K.-H. Genipin enhances the antitumor effect of elesclomol in A549 lung cancer cells by blocking uncoupling protein-2 and stimulating reactive oxygen species production. Oncol. Lett. 2020, 20, 374. [CrossRef]

44. Kreiter, J.; Rupprecht, A.; Zimmermann, L.; Moschinger, M.; Rokitskaya, T.; Antonenko, Y.N.; Gille, L.; Fedorova, M.; Pohl, E.E. Molecular Mechanisms Responsible for Pharmacological Effects of Genipin on Mitochondrial Proteins. Biophys. J. 2019, 117, 1845-1857. [CrossRef]

45. Vallejo, F.A.; Vanni, S.; Graham, R.M. UCP2 as a Potential Biomarker for Adjunctive Metabolic Therapies in Tumor Management. Front. Oncol. 2021, 11, 640720. [CrossRef]

46. Kim, B.R.; Jeong, Y.A.; Jo, M.J.; Park, S.H.; Na, Y.J.; Kim, J.L.; Jeong, S.; Yun, H.K.; Kang, S.H.; Lee, D.-H.; et al. Genipin Enhances the Therapeutic Effects of Oxaliplatin by Upregulating BIM in Colorectal Cancer. Mol. Cancer Ther. 2019, 18, 751-761. [CrossRef]

47. Gupta, A.K.; Roy, S.; Das, P.K. Antileishmanial effect of the natural immunomodulator genipin through suppression of host negative regulatory protein UCP2. J. Antimicrob. Chemother. 2020, 76, 135-145. [CrossRef]

48. Nguyen, U.T.; Nguyen, L.T.H.; Kim, B.-A.; Choi, M.-J.; Yang, I.-J.; Shin, H.-M. Natural Compound Mixture, Containing Emodin, Genipin, Chlorogenic Acid, Cimigenoside, and Ginsenoside Rb1, Ameliorates Psoriasis-Like Skin Lesions by Suppressing Inflammation and Proliferation in Keratinocytes. Evid.-Based Complement. Altern. Med. 2020, 2020, 9416962. [CrossRef]

49. Kim, B.R.; Jeong, A.Y.; Kim, D.Y.; Kim, J.L.; Jeong, S.; Na, Y.J.; Yun, H.K.; Park, S.H.; Jo, M.J.; Ashktorab, H.; et al. Genipin increases oxaliplatin-induced cell death through autophagy in gastric cancer. J. Cancer 2020, 11, 460-467. [CrossRef]

50. Huang, A.-G.; Tan, X.-P.; Qu, S.-Y.; Wang, G.-X.; Zhu, B. Evaluation on the antiviral activity of genipin against white spot syndrome virus in crayfish. Fish Shellfish Immunol. 2019, 93, 380-386. [CrossRef]

51. Xia, Q.; Dong, J.; Li, L.; Wang, Q.; Liu, Y.; Wang, Q. Discovery of Glycosylated Genipin Derivatives as Novel Antiviral, Insecticidal, and Fungicidal Agents. J. Agric. Food Chem. 2018, 66, 1341-1348. [CrossRef]

52. Ko, J.-W.; Shin, N.-R.; Park, S.-H.; Cho, Y.-K.; Kim, J.-C.; Seo, C.-S.; Shin, I.-S. Genipin inhibits allergic responses in ovalbumininduced asthmatic mice. Int. Immunopharmacol. 2017, 53, 49-55. [CrossRef]

53. Yu, D.; Shi, M.; Bao, J.; Yu, X.; Li, Y.; Liu, W. Genipin ameliorates hypertension-induced renal damage via the angiotensin II-TLR/MyD88/MAPK pathway. Fitoterapia 2016, 112, 244-253. 
54. Zhang, A.; Wang, S.; Zhang, J.; Wu, H. Genipin alleviates LPS-induced acute lung injury by inhibiting NF-kappaB and NLRP3 signaling pathways. Int. Immunopharmacol. 2016, 38, 115-119.

55. Zhong, S.; Wu, B.; Wang, X.; Sun, D.; Liu, D.; Jiang, S.; Ge, J.; Zhang, Y.; Liu, X.; Zhou, X.; et al. Identification of driver genes and key pathways of prolactinoma predicts the therapeutic effect of genipin. Mol. Med. Rep. 2019, 20, 2712-2724. [CrossRef]

56. Wang, M.; Yang, Z.-K.; Liu, H.; Li, R.-Q.; Liu, Y.; Zhong, W.-J. Genipin inhibits the scleral expression of miR-29 and MMP2 and promotes COL1A1 expression in myopic eyes of guinea pigs. Graefe's Arch. Clin. Exp. Ophthalmol. 2020, 258, 1031-1038. [CrossRef]

57. Ahani, N.; Sangtarash, M.H.; Houshmand, M.; Eskandani, M.A. Genipin induces cell death via intrinsic apoptosis pathways in human glioblastoma cells. J. Cell. Biochem. 2018, 120, 2047-2057. [CrossRef]

58. Chang, C.-H.; Wu, J.-B.; Yang, J.-S.; Lai, Y.-J.; Su, C.-H.; Lu, C.-C.; Hsu, Y.-M. The Suppressive Effects of Geniposide and Genipin on Helicobacter pylori Infections In Vitro and In Vivo. J. Food Sci. 2017, 82, 3021-3028. [CrossRef]

59. Dando, I.; Pacchiana, R.; Pozza, E.D.; Cataldo, I.; Bruno, S.; Conti, P.; Cordani, M.; Grimaldi, A.; Butera, G.; Caraglia, M.; et al. UCP2 inhibition induces ROS/Akt/mTOR axis: Role of GAPDH nuclear translocation in genipin/everolimus anticancer synergism. Free Radic. Biol. Med. 2017, 113, 176-189. [CrossRef]

60. Luo, R.; Lin, M.; Zhang, C.; Shi, J.; Zhang, S.; Chen, Q.; Hu, Y.; Zhang, M.; Zhang, J.; Gao, F. Genipin-crosslinked human serum albumin coating using a tannic acid layer for enhanced oral administration of curcumin in the treatment of ulcerative colitis. Food Chem. 2020, 330, 127241. [CrossRef]

61. Tacias-Pascacio, V.G.; García-Parra, E.; Vela-Gutiérrez, G.; Virgen-Ortiz, J.J.; Berenguer-Murcia, Á.; Alcántara, A.R.; FernandezLafuente, R. Genipin as An Emergent Tool in the Design of Biocatalysts: Mechanism of Reaction and Applications. Catalysts 2019, 9, 1035. [CrossRef]

62. Yu, Y.; Xu, S.; Li, S.; Pan, H. Genipin-cross-linked hydrogels based on biomaterials for drug delivery: A review. Biomater. Sci. 2021, 9, 1583-1597. [CrossRef]

63. Hobbs, C.A.; Koyanagi, M.; Swartz, C.; Davis, J.; Maronpot, R.; Recio, L.; Hayashi, S.-M. Genotoxicity evaluation of the naturally-derived food colorant, gardenia blue, and its precursor, genipin. Food Chem. Toxicol. 2018, 118, 695-708. [CrossRef]

64. Kim, M.-H.; Lee, M.-H.; Hwang, Y.S. Natural Blue Pigment from Gardenia jasminoides Ellis (Rubiaceae) as a Dental Plaque Disclosant. J. Dent. Hyg. Sci. 2021, 21, 38-44. [CrossRef]

65. Baell, J.B.; Nissink, J.W.M. Seven Year Itch: Pan-Assay Interference Compounds (PAINS) in 2017-Utility and Limitations. ACS Chem. Biol. 2018, 13, 36-44. [CrossRef]

66. Neri-Numa, I.A.; Pessôa, M.G.; Arruda, H.S.; Pereira, G.A.; Paulino, B.N.; Angolini, C.F.F.; Ruiz, A.L.T.G.; Pastore, G.M. Genipap (Genipa americana L.) fruit extract as a source of antioxidant and antiproliferative iridoids. Food Res. Int. 2020, 134, 109252. [CrossRef]

67. Ma, H.-F.; Meng, G.; Cui, B.; Si, J.; Dai, Y.-C. Chitosan crosslinked with genipin as supporting matrix for biodegradation of synthetic dyes: Laccase immobilization and characterization. Chem. Eng. Res. Des. 2018, 132, 664-676. [CrossRef]

68. Shin, J.-K.; Lee, S.-M. Genipin protects the liver from ischemia/reperfusion injury by modulating mitochondrial quality control. Toxicol. Appl. Pharmacol. 2017, 328, 25-33. [CrossRef]

69. Zhao, B.; Sun, L.-K.; Jiang, X.; Zhang, Y.; Kang, J.; Meng, H.; Li, H.; Su, J. Genipin protects against cerebral ischemia-reperfusion injury by regulating the UCP2-SIRT3 signaling pathway. Eur. J. Pharmacol. 2019, 845, 56-64. [CrossRef]

70. Xu, Y.; Wang, L.; Cao, S.; Hu, R.; Liu, R.; Hua, K.; Guo, Z.; Di, H.-J.; Hu, Z. Genipin improves reproductive health problems caused by circadian disruption in male mice. Reprod. Biol. Endocrinol. 2020, 18, 122. [CrossRef]

71. Kim, J.-H.; Kim, K.; Kim, W. Genipin inhibits rotavirus-induced diarrhea by suppressing viral replication and regulating inflammatory responses. Sci. Rep. 2020, 10, 15836. [CrossRef]

72. Nguyen, L.T.H.; Ahn, S.H.; Nguyen, U.T.; Yang, I.J.; Shin, H.M. Geniposide, a Principal Component of Gardeniae Fructus, Protects Skin from Diesel Exhaust Particulate Matter-Induced Oxidative Damage. Evid.-Based Complement. Altern. Med. 2021, 2021, 8847358. [CrossRef] 